\title{
Cytogenetical analyses in three fish species of the genus Pimelodus (Siluriformes: Pimelodidae) from rio São Francisco: considerations about the karyotypical evolution in the genus
}

\author{
Caroline Garcia and Orlando Moreira Filho
}

Karyotypes and other chromosomal markers were investigated in three species of the catfish genus Pimelodus, namely P. fur, P. maculatus and Pimelodus sp., from municipality of Três Marias, Minas Gerais, Brazil, using differential staining techniques (C-banding, Silver nitrate and $\mathrm{CMA}_{3}$ staining). The diploid chromosome number was $2 \mathrm{n}=56$ in P. maculatus and Pimelodus $s p$., while in $P$. fur $2 \mathrm{n}=54$. The karyotype of $P$. fur consisted in $32 \mathrm{M}+8 \mathrm{SM}+6 \mathrm{ST}+8 \mathrm{~A}$ with fundamental number (NF) of 100 , that of $P$. maculatus $32 \mathrm{M}+12 \mathrm{SM}+12 \mathrm{~A}$ with $\mathrm{NF}=112$, and that of Pimelodus $s p$. had $32 \mathrm{M}+12 \mathrm{Sm}+6 \mathrm{ST}+6 \mathrm{~A}$ with $\mathrm{NF}=106 . \mathrm{The}$ nucleolar organizer regions (NORs) in all three species were invariably detected in telomeres of longer arm of the $20^{\text {th }}$ chromosome pair. These sites were also positive after $\mathrm{CMA}_{3}$ and C-banding. No heteromorphic sex chromosomes were detected and C-banding pattern was species specific. Inferences about the karyotype differentiation in Pimelodus and putative chromosomal rearrangements are hypohesized.

Cariótipos e outros marcadores cromossômicos de três espécies do gênero Pimelodus denominadas, P. fur, P. maculatus e Pimelodus sp., do município de Três Marias, Minas Gerais, Brasil, foram analisados utilizando técnicas de coloração diferenciais (Bandamento C, coloração por nitrato de prata e $\mathrm{CMA}_{3}$ ). O número diplóide observado foi $2 \mathrm{n}=56 \mathrm{em}$ P. maculatus e Pimelodus $s p$., enquanto em $P$. fur $2 \mathrm{n}=54$. O cariótipo de $P$. fur consistiu em $32 \mathrm{M}+8 \mathrm{SM}+6 \mathrm{ST}+8 \mathrm{~A}$ com número fundamental (NF) igual a 100 , o de $P$. maculatus $32 \mathrm{M}+12 \mathrm{SM}+12 \mathrm{~A}$ com NF $=112$, e o de Pimelodus $s p$. possuía $32 \mathrm{M}+12 \mathrm{Sm}+6 \mathrm{ST}+6 \mathrm{~A}$ com $\mathrm{NF}=$ 106. As regiões organizadoras nucleolares (RONs) foram detectadas invariavelmente, para as três espécies, na região telomérica do braço longo do $20^{\circ}$ par cromossômico, estas se mostraram positivamente coradas pela $\mathrm{CMA}_{3}$ e heterocromáticas. Nenhuma diferença cromossômica entre os sexos foi detectada e o padrão de bandamento $\mathrm{C}$ foi espécie-específico Inferências sobre a evolução cariotípica dentro do gênero Pimelodus e os possíveis rearranjos cromossômicos envolvidos neste processo são discutidos.

Key words: Fish cytogenetics, diploid number reduction, chromosomal rearrangements, chromosome banding, catfishes

\section{Introduction}

The rio São Francisco basin is the fourth most important Brazilian basin, comprising nearly $7,4 \%$ of national territory, which includes North, Northeastern and Center-Western regions (Paiva, 1982). According to Britski et al. (1988), 133 fish species were described in the São Francisco and 57 of them occur at Três Marias, including: endemic catfish species Pimelodus fur and Pimelodus sp., and P. maculatus, also found in the rio Paraná basin. These three species are representatives of the family Pimelodidae and share several morphological similarities, being identified especially by their color patterns.
The family Pimelodidae is one of the most important speciose groups within Siluriformes that includes 31 recognized genera and 83 valid species (Lundberg \& Littmanm, 2003). Pimelodus, with 24 species (Lundberg \& Littmanm, 2003) is one of most cytogenetically studied genus of Pimelodidae. It is widespread throughout South American rivers, comprising endemic species, such as P. ortomanni (rio Iguaçu basin, Southern Brazil), as well as widely distributed ones, like $P$. maculatus.

The genus Pimelodus is known by the presence of the diploid number $2 \mathrm{n}=56$ associated with great variation in karyotype composition (Swarça et al., 2000). Only one case of structural polymorphism was detected in this genus (Dias \& Foresti, 1993).

Universidade Federal de São Carlos, Departamento de Genética e Evolução, Laboratório de Citogenética. Rodovia Washington Luis, km 235, PO Box 676, 13665-905 São Carlos, SP, Brazil. e-mail: omfilho@power.ufscar.br 
In the present work, cytogenetic analyses were carried out in three species of Pimelodus from rio São Francisco, in order to provide useful information for both chromosomal characterization of these species and identification of putative chromosomal rearrangements involved in the evolution of the group.

\section{Material and Methods}

Materials included the following three species of Pimelodus: P. fur (10 females +6 males), P. maculatus (10 females +3 males), and Pimelodus sp. (15 females +10 males), from rio São Francisco, collected at the municipality of Três Marias, Minas Gerais, Brazil. Identification of some specimens as "Pimelodus sp." followed the diagnostic characters presented by Britski et al. (1988). Voucher specimens are kept at the fish collection of Museu de Zoologia da Universidade de São Paulo, São Paulo, Brazil, under numbers: MZUSP 86908 - P. fur, MZUSP 86907 - P. maculatus and MZUSP 86909 Pimelodus sp..

Mitotic chromosomes were obtained from kidney cells using the direct preparation technique modified from Bertollo et al. (1978). Chromosomal morphology was determined according to arm ratio as proposed by Levan et al. (1964). The fundamental number (FN) was determined considering metacentric (M), submetacentric (SM) and subtelocentric (ST) chromosomes as biarmed, and acrocentric (A) as uniarmed. Nucleolar organizer regions (NORs) were visualized by silver staining (Ag-NOR), according to Howell \& Black (1980). The base-specific fluorochrome staining was performed according to Schmid (1980) using the GC-specific fluorochrome Chromomycin $\mathrm{A}_{3}\left(\mathrm{CMA}_{3}\right)$. The $\mathrm{C}$-banding was performed as described by Sumner (1972).

\section{Results}

P. fur had $2 \mathrm{n}=54$ and the karyotype composed of $32 \mathrm{M}+$ $8 \mathrm{SM}+6 \mathrm{ST}+8 \mathrm{~A}$, and $\mathrm{FN}=100$ (Fig. 1a). P. maculatus $2 \mathrm{n}=$ 56 , the karyotype $32 \mathrm{M}+12 \mathrm{SM}+12 \mathrm{ST}$ and $\mathrm{FN}=112$ (Fig. 1b), Pimelodus $s p .2 \mathrm{n}=56$, and the karyotype $32 \mathrm{M}+12 \mathrm{SM}+6 \mathrm{ST}$ $+6 \mathrm{~A}$, and $\mathrm{FN}=106$ (Fig. 1c).

Single Ag-NORs located at terminal position of the long arms of $20^{\text {th }}$ chromosome pair was observed in all three species (Fig. 1 boxes). An NOR-size heteromorphism between homologous in $P$. fur. was also observed

C-banding pattern was peculiar for each species. The NOR sites were C-band positive. P. fur and Pimelodus sp. (Fig. 2a and $2 \mathrm{c}$ ) had C-band positive blocks distributed over pericentromeric and terminal regions of most of chromosomes. In Pimelodus sp., C-band positive segments were also observed in both terminal regions of a pair of $\mathrm{M}$ chromosomes. P. maculatus had the lowest amount of C-band positive segments, located in pericentromeric regions (Fig. 2b).

$\mathrm{CMA}_{3}$ staining revealed positive fluorescent signals cor-

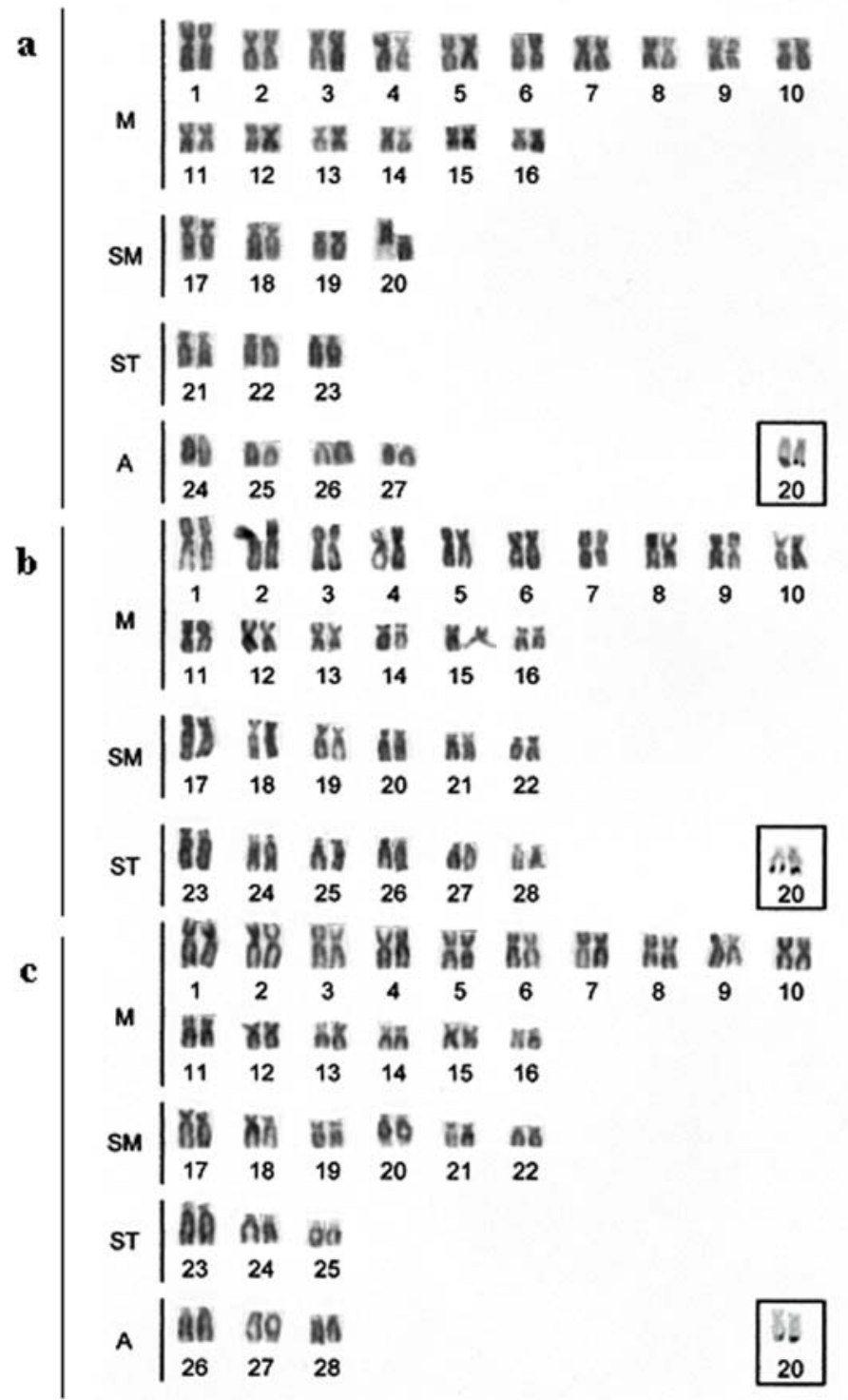

Fig. 1. Karyotypes of: a) P. fur, b) P. maculatus, and c) Pimelodus sp. arranged from Giemsa-stained . Ag-NOR-bearing pair is framed.

responding to Ag-positive signals in all three species. Moreover, other fluorescent signals corresponding with some other C-band positive segments were also observed in Pimelodus $s p$. (Figs. 2d, 2e, and 2f).

\section{Discussion}

The present work reports on the diploid number lower than $2 \mathrm{n}=56$ among catfishes of the genus Pimelodus. The descrease in $2 \mathrm{n}$ in $P$. fur is likely due to the chromosomal rearrangement of fusion or translocation type. On the other hand, a diploid number higher than $2 \mathrm{n}=56$ was reported for $P$. blochii where equals $2 \mathrm{n}=58$ (Della-Rosa et al., 1980).

Oliveira \& Gosztonyi (2000) suggested that $2 \mathrm{n}=56$ chro- 

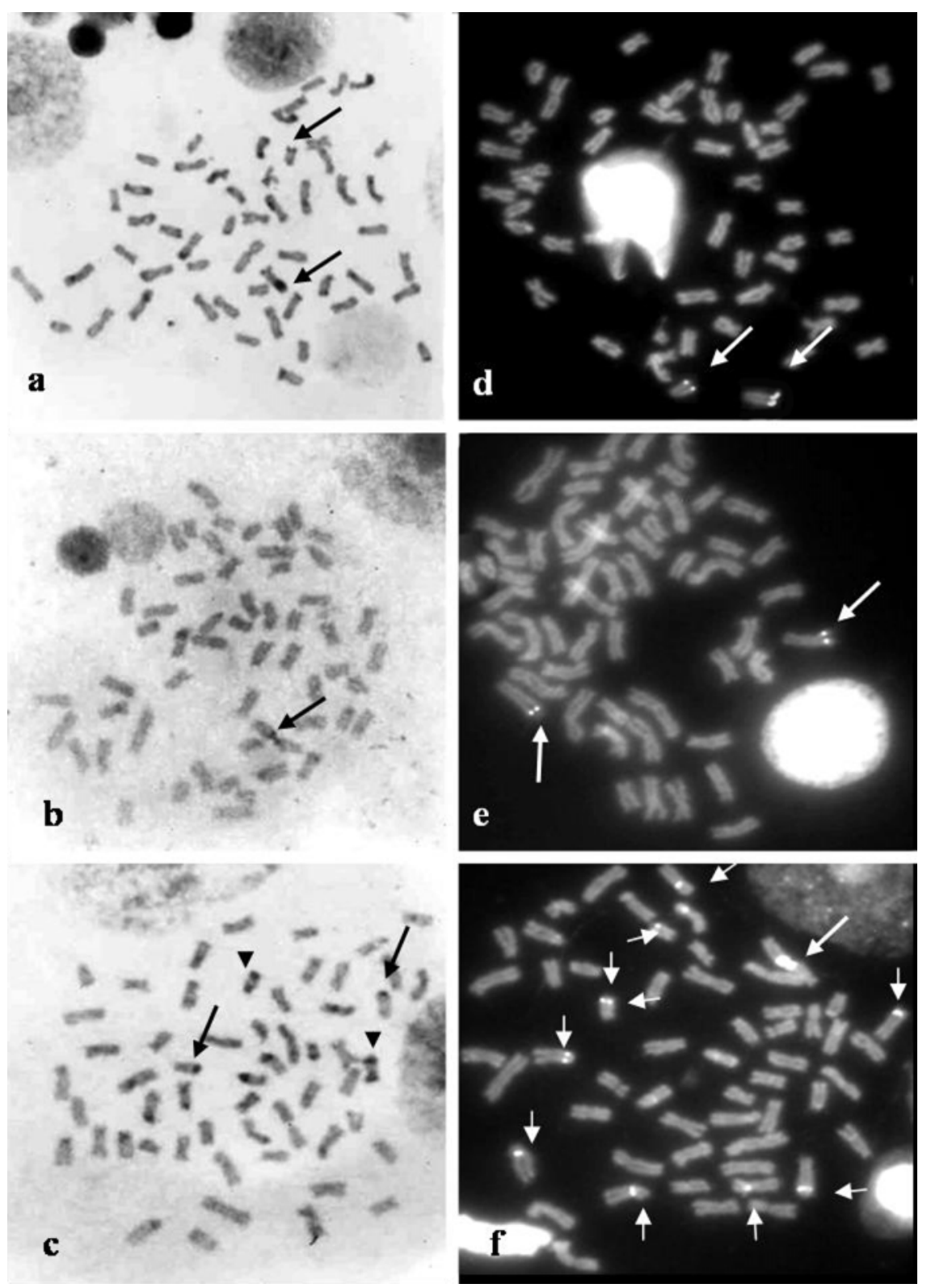

Fig. 2. Somatic chromosome metaphases of P. fur (a, d), P. maculatus (b, e) and Pimelodus sp. (c, $\mathrm{f})$ submitted to: $\mathrm{C}$ banding (a, $\mathrm{b}, \mathrm{c})$ and staining with $\mathrm{CMA}_{3}(\mathrm{~d}, \mathrm{e}, \mathrm{f})$. The major arrows indicate the NOR-bearing pairs. NOR association $(\mathrm{b}, \mathrm{f})$ and NOR size heteromorphism (a) are exemplified. The arrows indicate positive chromosome regions corresponding with heterochromatin sites after treatment with fluorochrome and the arrowheads indicate a pair of metacentric chromosomes with both telomeres heterochromatic.

mosomes is the ancestral diploid number within Siluriformes. Therefore, the presence of this diploid number could be considered a plesiomorphic condition of the genus Pimelodus, also, while modifications (alterations) of $2 \mathrm{n}$ such as those detected in P. fur $(2 \mathrm{n}=54)$ and/or P. blochii $(2 \mathrm{n}=58)$ may represent rare and apomorphic characters.

Despite of the different diploid chromosome numbers, the species under study have similar if not identical karyotypes : all of them have the same number of $M$ chromosomes (32) of similar size as well as NORs located at terminal position of longer arm of the $20^{\text {th }}$ pair of chromosomes. This karyotype uniformity might indicate their closely evolutionary relationship.

New observation is the absence of A chromosomes in the karyotype of P. maculatus. Specimens under study as yet, the lowest number of A chromosomes was one pair (Pimelodus sp. from Iguaçu river, Souza et al., 2004a), whereas the highest was six pairs (P. fur, P. maculatus and Pimelodus sp., Toledo \& Ferrari, 1976). The most frequent pattern in the genus is the presence of three pairs of Achromosomes (Vissoto et al., 1999; Swarça et al., 2001; Borin \& Martins-Santos, 2002) and the lack observed in P. maculatus could be a result of 
non-Robertsonian rearrangements, such as pericentric inversions.

Pericentric inversions have been considered one of the major chromosomal rearrangements responsible for the karyotype variability in a number of fish groups, particularly in those with conservative uniform diploid number, such as e.g. Acestrorhynchinae and Cynopotaminae (Falcão \& Bertollo, 1985), Serrasalminae (Cestari \& Galleti Jr., 1992), Parodontidae (Jesus et al., 1999; Jorge \& Moreira-Filho, 2000), Trichomycteridae (Borin \& Martins-Santos, 1999), Hypoptomatinae (Artoni \& Bertollo, 2001), Pomacanthidae (Affonso et al., 2002), Neoplecostominae (Kavalco et al., 2005) among others.

Based on the available cytogenetic data for the family Pimelodidae, and Siluriformes as well, we hypothesis that pericentric inversions appear to be an important, if not the most common rearrangement karyotype differentiation in the family keeping the diploid number but diversifying the karyotype morphology.

Dias \& Foresti (1993) have also analyzed P. maculatus and Pimelodus sp. from rio São Francisco. They reported the same karyotype composition for both species (40 M/SM + 16 $\mathrm{ST} / \mathrm{A}$ ), besides the occurrence of a structural polymorphism. Their results however do not agree with our data, differences between both reports can be attributed to fact that chromosomes were assigned into particular categories on the basis of differently condensated chromosomes.

Ag-NOR analyses confirmed that the species under study retain the pattern observed in the genus, i.e., a predominance of single Ag-NORs at terminal position of longer arm of ST chromosomes (Dias \& Foresti, 1993; Vissoto et al., 1999; Borin $\&$ Martins-Santos, 2002). On the other hand, the occurrence of Ag-NORs at chromosomal short arms appears to be relatively rare (Borin \& Martins-Santos, 2002; Souza et al., 2003).

The NOR sites of the three species were C-positive and thus heterochromatic, as also reported in another population of P. maculatus (Swarça et al., 2001a). A size heteromorphism of these sites between homologues was frequently observed in P. fur after C-banding, $\mathrm{CMA}_{3}$ and $\mathrm{Ag}$ - nitrate staining. Such size heteromorphism has been frequently reported in Pimelodidae (Gil et al., 1998; Vissoto et al., 1999; Swarça et al., 1999, Souza et al., 2004a, b). Because of their redundancy, the rDNA regions are likely more susceptible to unequal crossing-over or chromosomal rearrangements, leading to size differences between NOR-bearing homologous, particularly if these sites are associated to heterochromatic regions (Moreira-Filho et al.,1984).

Correspondence between $\mathrm{CMA}_{3}$ and $\mathrm{Ag}-\mathrm{NOR}$ sites were observed in several pimelodid species, such as Pirinampus pirinampu (Swarça et al., 1999), Zungaro zungaro (Swarça et al., 2001b), Pimelodus maculatus (Swarça et al.,2001a; Borin \& Martins-Santos, 2002), P. abscontidus and P. ornatus (Borin \& Martins-Santos, 2002), and P. argentus and $P$. mysteriosus (Souza et al., 2003). In the present study, the same correspondence between $\mathrm{CMA}_{3}$ and Ag-NOR positive sites was observed. Besides, other fluorescent signals were detected in C-band positive chromatin of Pimelodus sp. documenting presence of heterochromatin of GC-type This character shows that this species presents a distinctive heterochromatin classes then other two species. A similar situation was reported in P. maculatus from rio Paraguay (Souza et al., 2003).

Species specific C-banding pattern permitted the determination of each species: P. fur and Pimelodus sp. had small Cband positive sites at the centromeric and terminal regions of some chromosomes, similarly to the pattern observed in this group (Vissoto et al., 1999; Borin \& Martins-Santos, 2002; Souza et al., 2003) while P. maculatus had less C-band positive segments.

Nevertheless, a pair of M chromosomes bearing C-band positive segments at both telomeres were observed in Pimelodus $s p$. only Similar C-banding pattern was reported in other species of the genus Pimelodus (Pimelodus sp. and P. heraldoi - Souza et al., 2004a; P. maculatus, P. ornatus and $P$. absconditus - Borin \& Martins-Santos, 2002) and some pimelodids and heptapterids (Pimelodella sp. - Vasconcelos \& Martins-Santos, 2000; Rhamdia sp. - Garcia et al., 2003; Iheringichthys labrosus - Carvalho et al., 2004). This situation is frequently reported in these catfishes, indicating that the presence of this chromosome pair could be a shared condition and a cytotaxonomic marker for both families.

The present study shows, for the first time, two peculiar situations for representatives of the genus Pimelodus: the occurrence of a lower diploid number in $P$. fur and the absence of A chromosomes in P. maculatus. These findings might be related to intrinsic features of São Francisco River basin, which could favor the endemism of fish species in this basin. The present results contribute to the evolutionary and cytogenetic understanding of the phylogenetic relationships within this genus and the family Pimelodidae.

\section{Acknowledgements}

The authors are grateful to Yoshimi Sato, CODEVASF, for the assistance in the sample collection. This work was supported by Fundação de Amparo à Pesquisa do Estado de São Paulo (FAPESP - Proc. 02/10516-0) and Conselho Nacional de Desenvolvimento Científico e Tecnológico (CNPq).

\section{Literature Cited}

Affonso, P. R. A. M., W. Guedes, E. Pauls \& P. M. Galetti Jr. 2002. Close karyotypical relationship between two species of marine angelfish from South Atlantic: Pocamanthus arcuatus and P. paru (Perciformes, Pomacanthidae). Caryologia, 55(4): 323-329.

Artoni, R. F. \& L. A. C. Bertollo. 2001. Trends in the karyotype evolution of Loricariidae fish (Siluriformes). Hereditas, 134: 201-210.

Bertollo, L. A. C., C. S. Takahashi \& O. Moreira-Filho. 1978. Cytotaxonomic considerations on Hoplias lacerdae (Pisces, Erythrinidae). Brazilian Journal of Genetics, 1: 103-120. 
Borin, I. A. \& I. C. Martins-Santos. 1999. Karyotype characterization of three species of the genus Trichomycterus (Telostei, Siluriformes) from Iguaçu river basin. Genetica, 106: 215-221.

Borin, I. A. \& I. C. Martins-Santos. 2002. Cytogenetic aspects in species of the genus Pimelodus (Pisces, Siluriformes, Pimelodidae) of the river Paraná Basin. Cytologia, 67: 199-204.

Britski, H. A., Y. Sato \& A. B. S. Rosa. 1988. Manual de identificação de peixes da região de Três Marias. Câmara dos Deputados/ CODEVASF, Brasília, Brazil, 143p.

Carvalho, A. C., Giuliano-Caetano, L. \& Dias, A. L. 2004. Cytogenetic analysis of A- and B-chromosomes of Iheringichthys labrosus (Pisces, Pimelodidae) from Tibagi River, Paraná, Brazil. Cytologia, 69(4): 381-385.

Cestari, M. M. \& P. M. Galetti Jr. 1992. Chromosome evolution in the genus Serrasalmus and cytotaxonomic considerations about Serrasalminae (Characidae, Pisces). Brasilian Journal of Genetics, 15(3): 555-567.

Della-Rosa, V. A., L. A. C. Bertollo, I. Ferrari, O. Moreira-Filho \& F. Foresti. 1980. Estudos citogenéticos de peixes da Amazônia. II Ordem Siluriformes. Ciência e Cultura, 32:735.

Dias, A. L. \& F. Foresti. 1993. Cytogenetic studies on fishes of the family Pimelodidae (Siluroidei). Brasilian Journal of Genetics, 16(3): 585-600.

Falcão, J. N. \& L. A. C. Bertollo. 1985. Chromosome characterization in Acestrorhynchinae and Cynoptomatinae (Pisces, Characidae). Journal of Fish Biology, 27: 157-163.

Garcia, C., O. Moreira-Filho, L. A. C. Bertollo \& L. Centofante. 2003. B chromosomes and natural triploidy in Rhamdia sp. (Pisces, Siluriformes, Heptapteridae). Cytologia, 68(4): 403-411.

Gil, H. R., E. Feldberg, V. M. F Almeida-Val \& A. L. Val. 1998. Karyological, biochemical, and physiological aspects of Callophysus macropterus (Siluriformes, Pimelodidae) from the Solimões and Negro Rivers (Central Amazon). Brazilian Journal of Medical and Biological Research, 31(11): 1449-1458.

Howell, W. M. \& D. A. Black. 1980. Controlled silver staining of nucleolus organizer regions with protective colloidal developer: a one-step method. Experientia, 36: 1014-1015.

Jesus, C. M., L. A. C. Bertollo \& O. Moreira-Filho. 1999. Comparative cytogenetic in Apareidon affinis (Pisces, Characiformes) and considerations regarding diversification of the group. Genetica, 105: 63-67.

Jorge, L. C. \& O. Moreira-Filho. 2000. Cytogenetic studies on Apareidon affinis (Pisces, Characiformes) from Paraná river basin: sex chromosomes and polymorphism. Genetica, 49: 1-7.

Kavalco, K. F., R. Pazza, L. A. C.Bertollo \& O. Moreira-Filho. 2005 Karyotypic diversity and evolution of Loricariidae (Pisces, Siluriformes). Heredity, 94: 180-186.

Levan, A., K. Fredga \& A. A. Sandberg. 1964. Nomenclature for centromeric position on chromosomes. Hereditas, 52: 201-220.

Lundberg, J. G. and M. W. Littmann. 2003. Pimelodidae. In: Check list of the freshwater fishes of South America,_R. E.
Reis, S. O. Kullander and C. J. Ferraris (eds.). Edipucrs, Porto Alegre, pp. 432 - 446.

Lundeberg, J. G., F. Mago-Leccia \& P. Nass. 1991. Exallodontus aguanai a new genus and species of Pimelodidae (Pisces, Siluriformes) from deep river channel of South America, and delimitation of the subfamily Pimelodinae. Proceedings of the Biological Society of Washington, 104(4): 840-869.

Moreira-Filho, O., L. A. C. Bertollo \& P.M. Galetti Jr. 1984 Structure and variability of nucleolar organizing regions in Paradontidae fish. Canadian Journal of Genetics and Cytology, 26(5): 564-568.

Oliveira, C. \& A. E. Gosztonyi. 2000. A cytogenetic study of Diplomystes mesembrinus (Teleostei, Siluriformes, Diplomystidae) with a discussion of chromosome evolution in siluriforms. Caryologia, 53(1): 31-37.

Paiva, M. P. 1982. Grandes represas do Brasil. Editerra Editorial.São Paulo, SP, Brazil, 292p.

Pinna, M. C. C. 1993. Higher-Level phylogeny of Siluriformes, with a new classification of the order (Telostei, Ostariophysi). Master Thesis. The City University of New York, New York.

Schmid, M. 1980. Chromosome banding in Amphibia: IV. Differentiation of GC and AT rich chromosomes regions in Anura. Chromosoma, 77: 83-103.

Souza, I. L. \& O. Moreira-Filho. 1995. Cytogenetic diversity in the Astyanax scabripinnis species complex. (Pisces, Characidae). I: Allopatric distribution in a small stream. Cytologia, 60: 1-14.

Souza, L., L.Giuliano-Caetano \& A.L. Dias. 2003. Karyotipic study of three species of Pimelodus (Pisces, Pimelodidae) from the Paraguay river basin. Cytologia, 68(4): 345-350.

Souza, L., L. Giuliano-Caetano \& A.L. Dias. 2004a. Banding chromosome pattern of two species of Pimelodus (Siluriformes, Pimelodidae) from the Paraná river basin of Brazil. Folia Biologica, 52(3-4):165-169.

Souza, L., A. C. Swarça,. \& A.L. Dias. 2004b. Analyses of the nucleolus organizer region in 5 species of the genus Pimelodus (Siluriformes, Pimelodidae) using $\mathrm{AgNO}_{3}$, $\mathrm{CMA}_{3}$ and FISH with $18 \mathrm{~S}$ rDNA probe. Caryologia, 57(2): 145-151.

Sumner, A.T. 1972. A simple technique for demonstrating centromeric heterochromatin. Experimental Cell Research, 75: 304-306.

Swarça, A. C., L. Giuliano-Caetano \& A.L. Dias. 1999. Cytogenetic characterization through chromosomic banding of Pinirampus pirinampu (Pisces, Pimelodidae) from the Tibagi River basin PR/Brazil. Caryologia, 52: 31-35.

Swarça, A. C., L.Giuliano-Caetano \& A. L. Dias. 2000. Cytogenetics of species of the families Pimelodidae e Rhamdiidae (Siluriformes). Genetics and Molecular Biology, 23(3): 589593.

Swarça, A. C., L. Giuliano-Caetano \& A.L. Dias. 2001a. Analyses of the nucleolus organizer region and heterochromatin of Pimelodus maculatus (Pisces, Pimelodidae). Genetica, 110: 97-100. 
Swarça, A. C., M. M. Cestari, L.Giuliano-Caetano \& A. L. Dias. 2001b. Cytogenetic characterization of the large South American siluriform fish species Zungaro zungaro (Pisces, Pimelodidae). Chromosome Science, 5: 51-55.

Toledo, V.\& I. Ferrari. 1976. Estudos citogenéticos de três espécies do gênero Pimelodus (Pisces, Pimelodidae). Cientifica, 4: 101-106.

Vasconcelos, C. \& I.C. Martins-Santos. 2000. Chromosome polymorphism in species of the Pimelodidae family (Pisces, Siluriformes). Hereditas, 132: 103-109.

Vissoto, P. C., F. Foresti \& C. Oliveira. 1999. Karyotype description of five species of Pimelodidae (Teleostei, Siluriformes). Chromosome Science, 3:1-7.

Received February 2005

Accepted May 2005 